\title{
ROLE OF USG AND MDCT IN EVALUATION OF URINARY BLADDER MASS
}

Sunny Goyal ${ }^{1}$, Tushar Prabha², Mohan Shivnani ${ }^{3}$, Ankur Aggarwal ${ }^{4}$, Hemant Kumar Mishra ${ }^{5}$

\section{HOW TO CITE THIS ARTICLE:}

Sunny Goyal, Tushar Prabha, Mohan Shivnani, Ankur Aggarwal, Hemant Kumar Mishra. "Role of USG and MDCT in Evaluation of Urinary Bladder Mass". Journal of Evolution of Medical and Dental Sciences 2014; Vol. 3, Issue 60, November 10; Page: 13490-13500, DOI: $10.14260 /$ jemds/2014/3801

INTRODUCTION: Primary bladder neoplasms account for $2 \%-6 \%$ of all tumors, with bladder cancer ranked as the fourth most common malignancy (1). Peak incidence is in the sixth and the seventh decades. Incidence is four times higher in men than in women.

The urinary bladder is the organ that collects urine excreted by the kidneys before disposal by urination. A hollow muscular, and distensible (or elastic) organ, the bladder sits on the pelvic floor. Urine enters the bladder via the ureters and exits via the urethra.(2) The bladder is readily identified by ultrasound, Computed Tomography, cystography, Magnetic Resonance Image (MRI) and Cystoscopy, but Bladder ultrasound is noninvasive, readily accessible, and easy to use. It has been extensively investigated as a possible substitution for some of the more common invasive modalities used to evaluate the bladder.(3)

Bladder cancer is the most common tumor of urinary tract. Sonographically, the distended urinary bladder should have smooth, thin, medium level echogenic walls (approximately $3 \mathrm{~mm}$ thick) and contain no echoes, with the exception of the normal jets of urine as the ureters empty into the bladder. In the partially filled state, the bladder is collapsed. The urinary bladder cavity is not seen if it is collapsed; otherwise it appears anechoic.

The bladder wall appears as a smooth, thin echogenic line. The sonographic appearances of a partially filled bladder are thickened (up to $6 \mathrm{~mm}$ thick), irregular walls encircling an echolucent interior. Therefore, to assess wall thickness, the bladder should be reasonably distended. The ureteral orifices are seen as elevations on the posterior portion of the bladder on longitudinal scans to each side of midline in transverse scans. ${ }^{(4)}$

\section{SIGN AND SYMPTOMS:}

- Hematuria.

- Urgency, frequency and strangury.

- Secondary infections result in cystitis.

- Tumor at bladder base causes obstructive symptoms.

- Pain secondary to clot retention into pelvis and urethral obstruction.

- Constitutional symptoms when distance metastasis occurs.

\section{RISK FACTORS:}

- Tobacco smoking.

- Occupation (exposure to aniline, benzidine and 5naphthylamine).

- Biological agents (coffee, beer, artificial sweeteners, grilled food).

- Exposure to radiation, chronic irritation of urothelium

- Abnormal tryptophan metabolism. 


\section{AIMS AND OBJECTIVE:}

- To Evaluate the role of USG and MDCT in detection of bladder neoplasm

- To detect the ability of USG and MDCT in staging of malignant neoplasm spread

- To correlate imaging findings of USG and MDCT with Histopathological findings

\section{MATERIALS \& METHODS:}

Study Location: Radiodiagnosis department of Mahatma Gandhi Medical College \& Hospital, Jaipur.

Study Design: Prospective analytical study of case records

Study Population: The study was conducted on patients who were referred from urology, surgery and medicine department with complains of hematuria.

Study Period: OCT 2012- Dec 2013.

Sample Size: Urinary Bladder cancer cases from Oct 2012- Dec 2013.

\section{Various types of presentation of bladder mass are as Follows:}

- CASE 1: UNIFOCAL MASS.

- CASE 2: MULTIFOCAL MASS.

- CASE 3: MASS AT APEX.

- CASE 4: MASS AS FOCAL BLADDER WALL THICKNING.

- CASE 5: MASS OBSTRUCTING UVJ CAUSING HYDRONEPHROSIS.

\section{CASE 1}
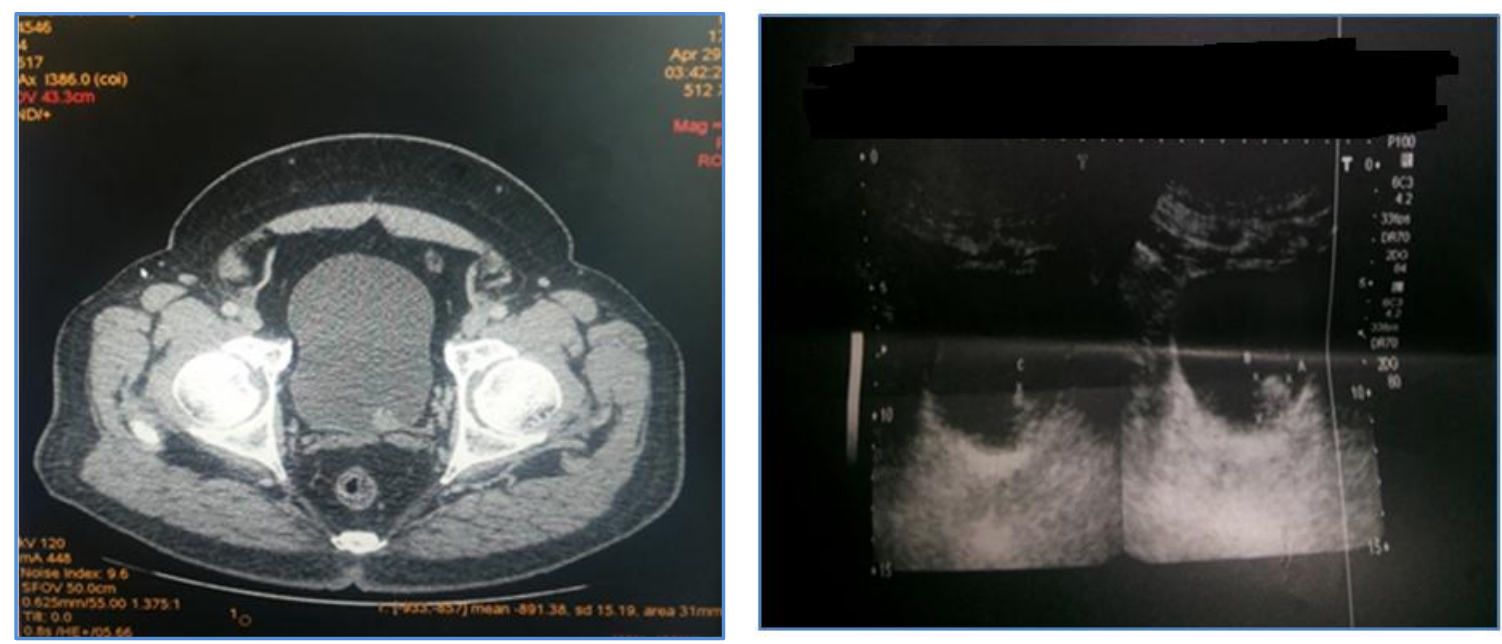


\section{CASE STUDY}

\section{CASE 2}
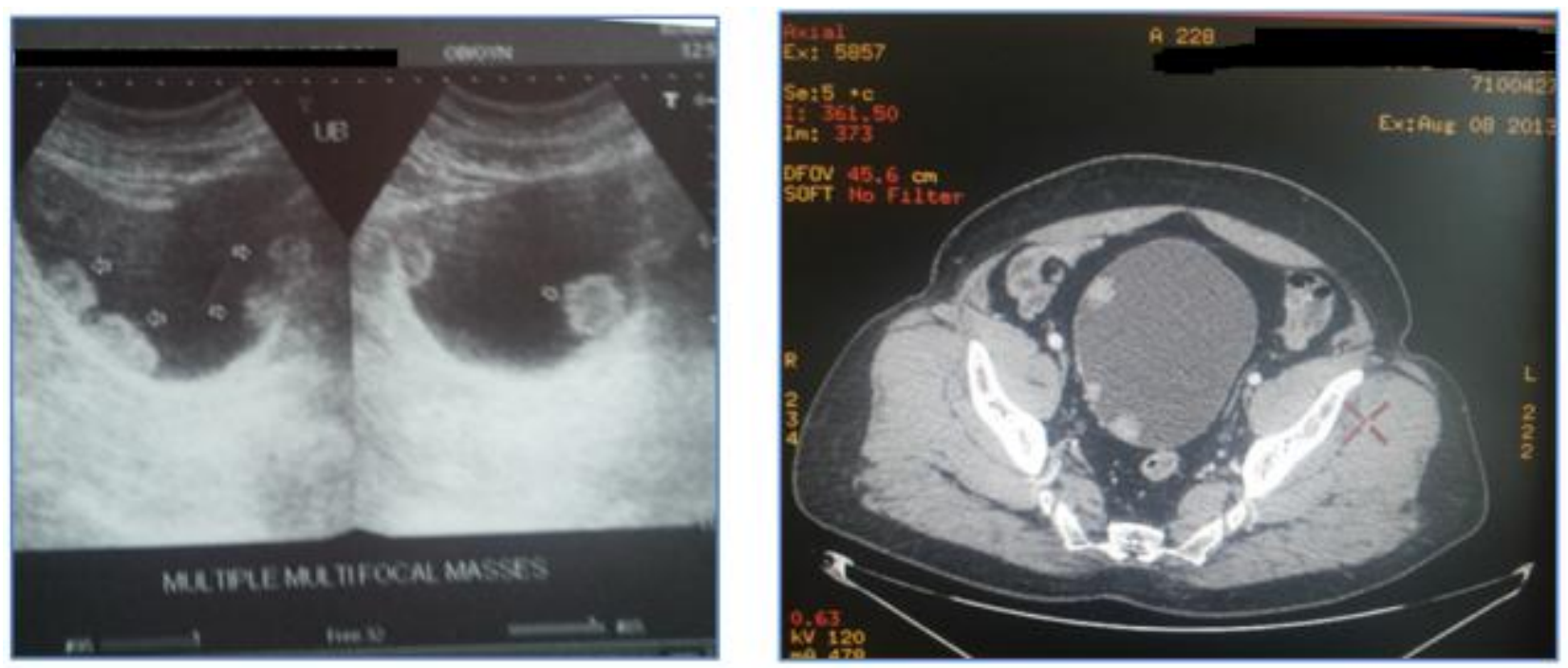

\section{CASE 3}
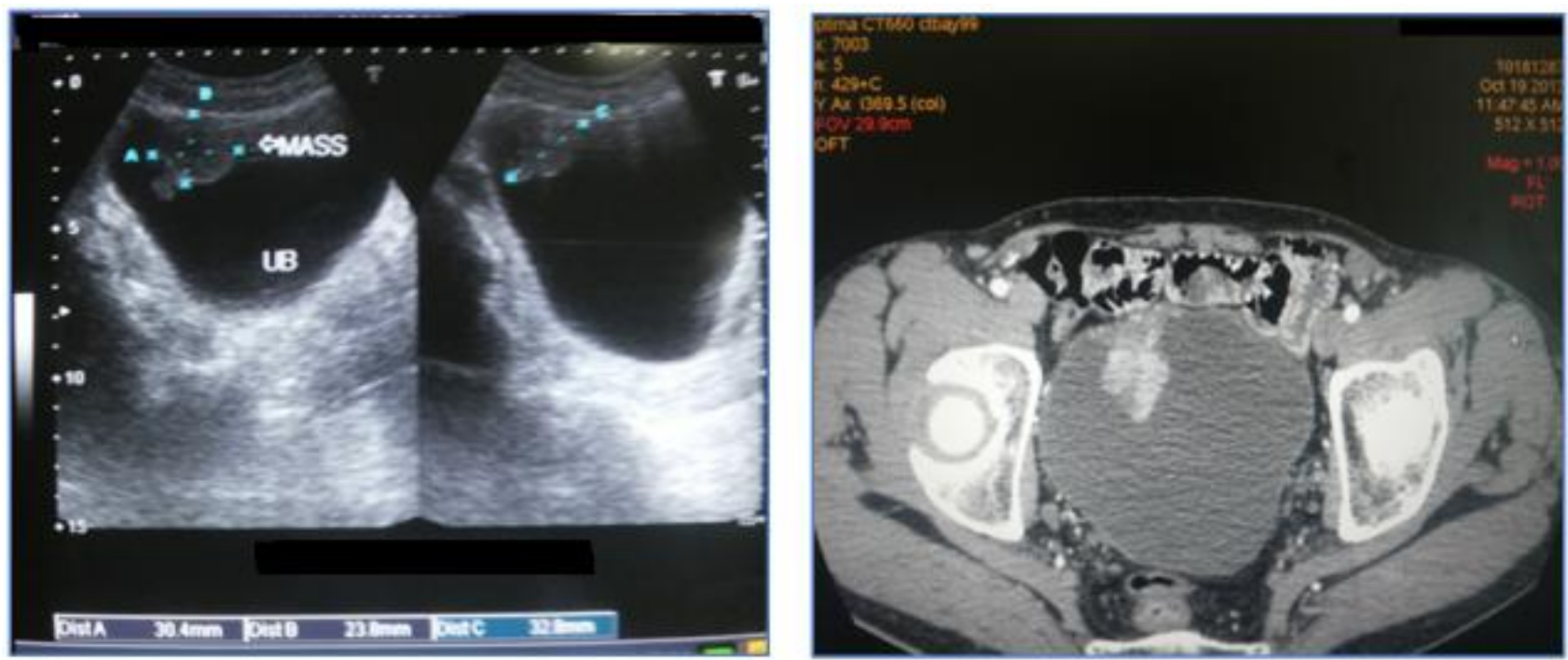


\section{CASE STUDY}

\section{CASE 4}
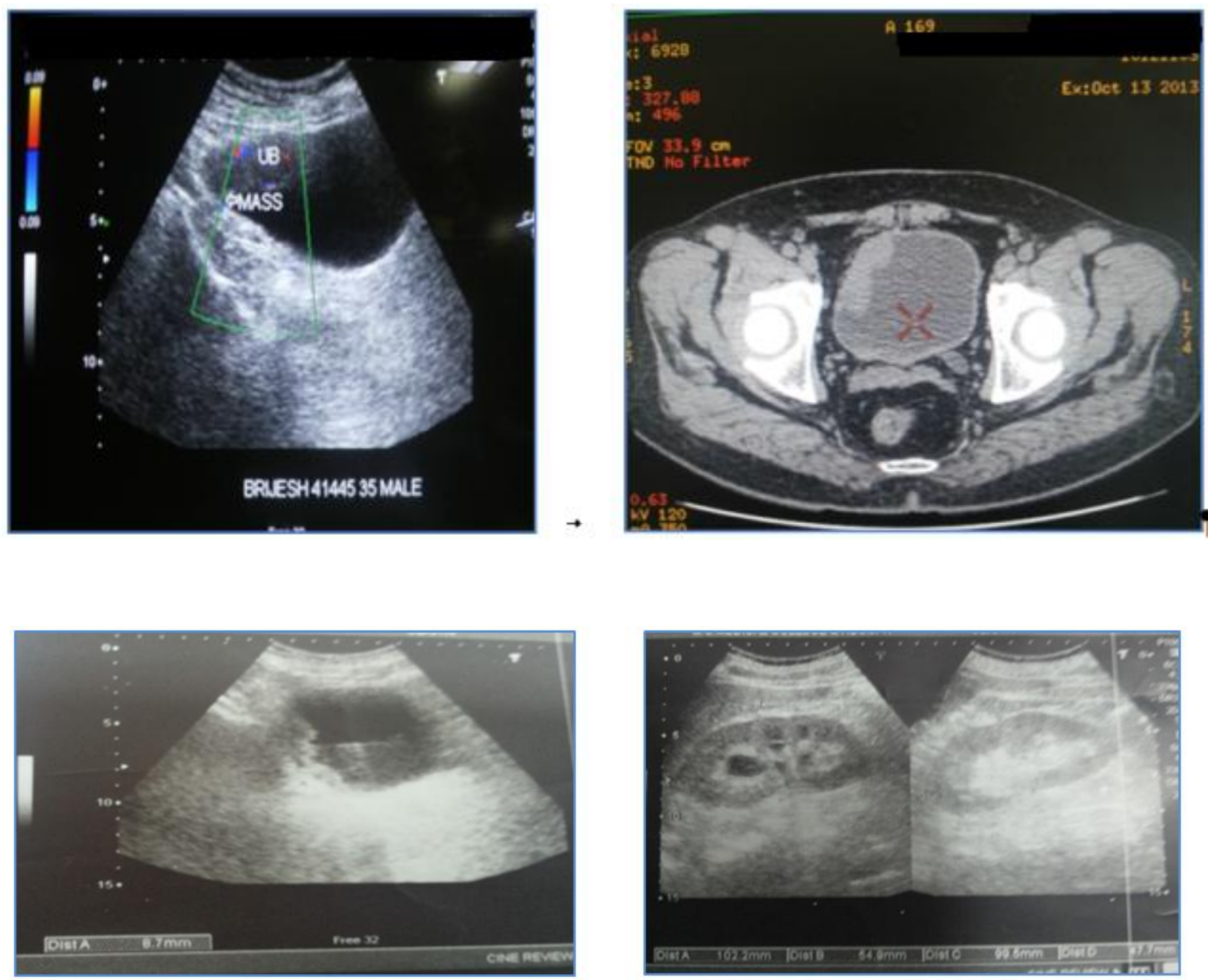

CASE 5
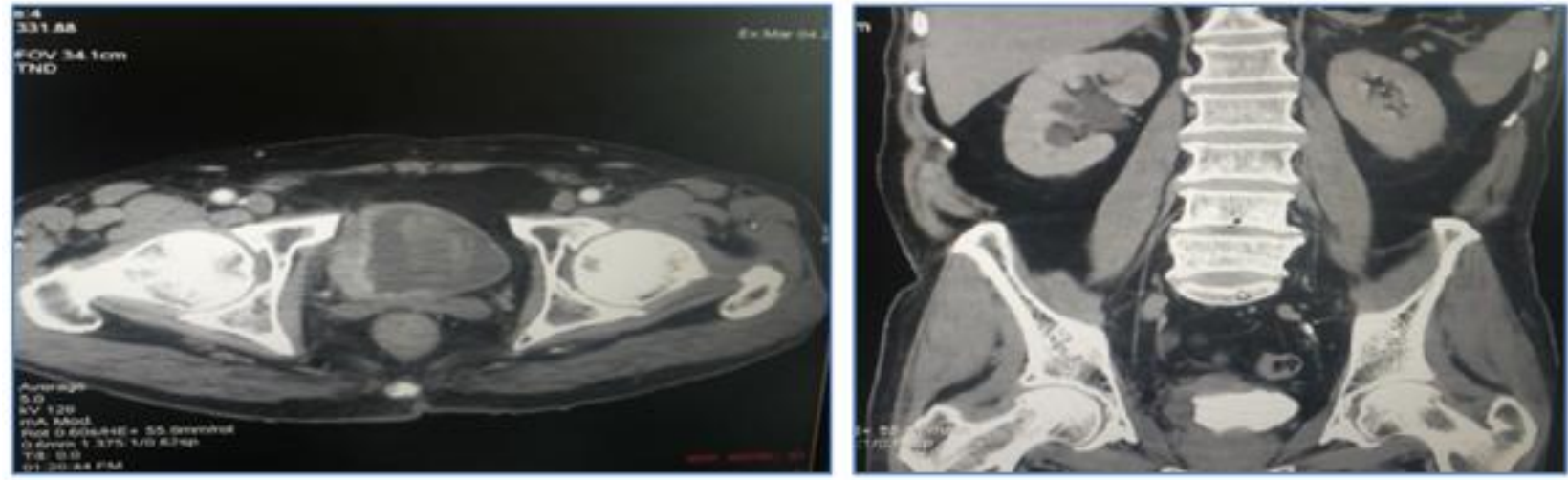
ANALYSIS:

\section{Age of Patient:}

\begin{tabular}{|l|l|l|}
\hline Years & No. of patients & Precentage \\
\hline $1-19$ & - & - \\
\hline $20-39$ & 6 & $5 \%$ \\
\hline $40-59$ & 12 & $30 \%$ \\
\hline $60-79$ & 1 & $60 \%$ \\
\hline $80-99$ & & $5 \%$ \\
\hline
\end{tabular}

AGE VS NUMBER OF PATIENTS:

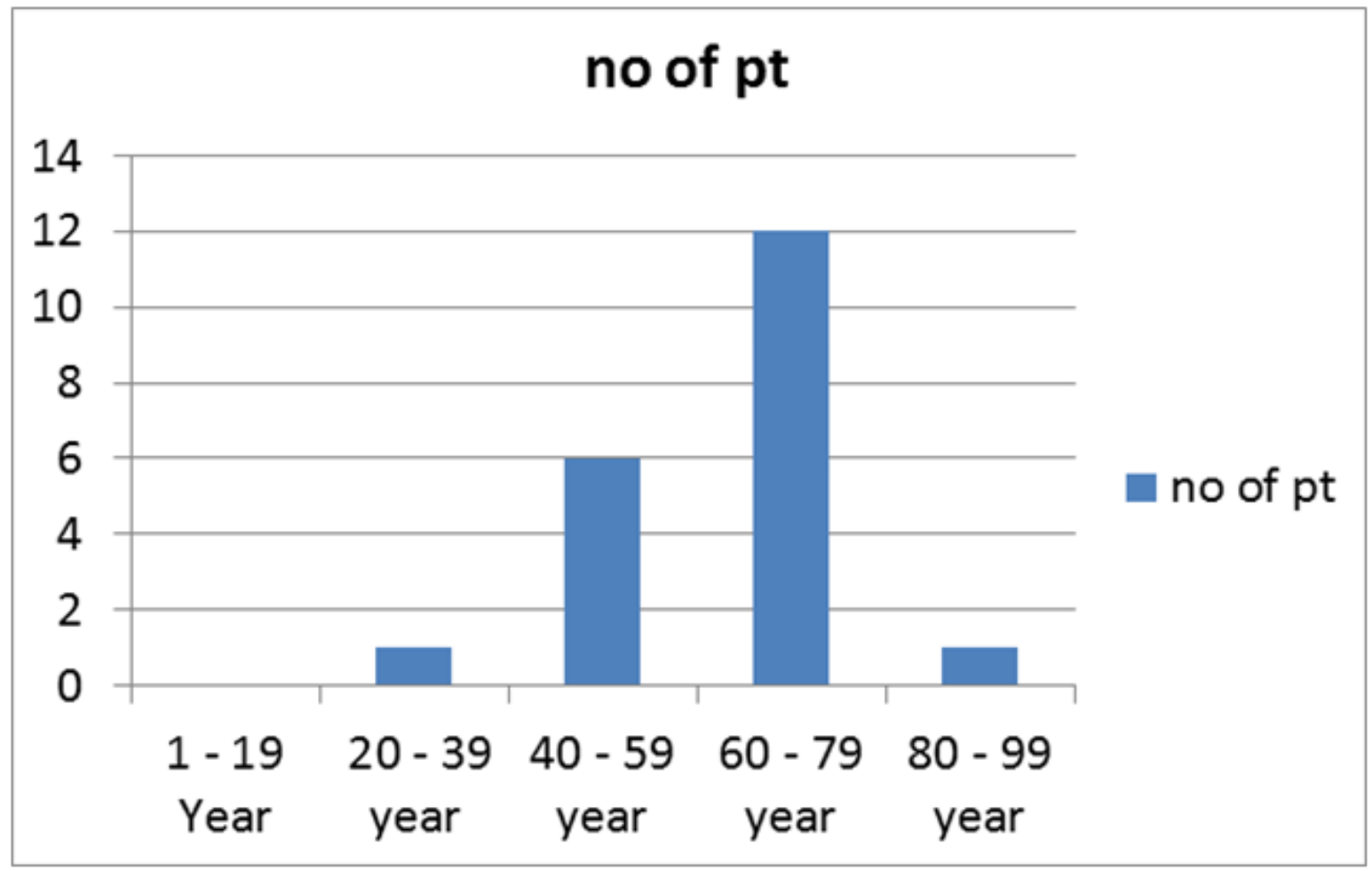




\section{CASE STUDY}

\section{Sex of the Patient:}

\begin{tabular}{|l|l|l|}
\hline Sex & No. of patient & $\%$ \\
\hline Male & 17 & $85 \%$ \\
\hline Female & 3 & $15 \%$ \\
\hline & & \\
\hline
\end{tabular}

PERCENTAGE OF MALES VS FEMALE:

\section{males vs females}

male females

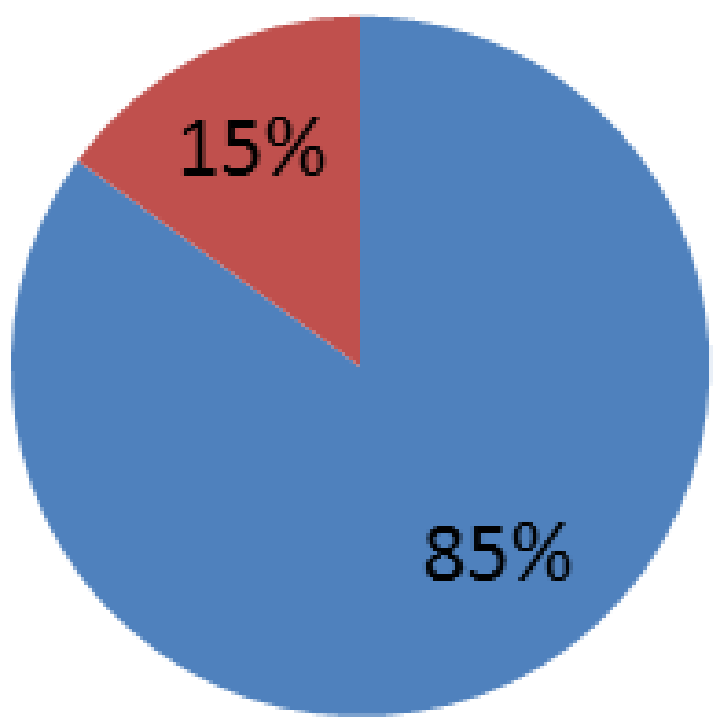




\section{Presenting Symptoms:}

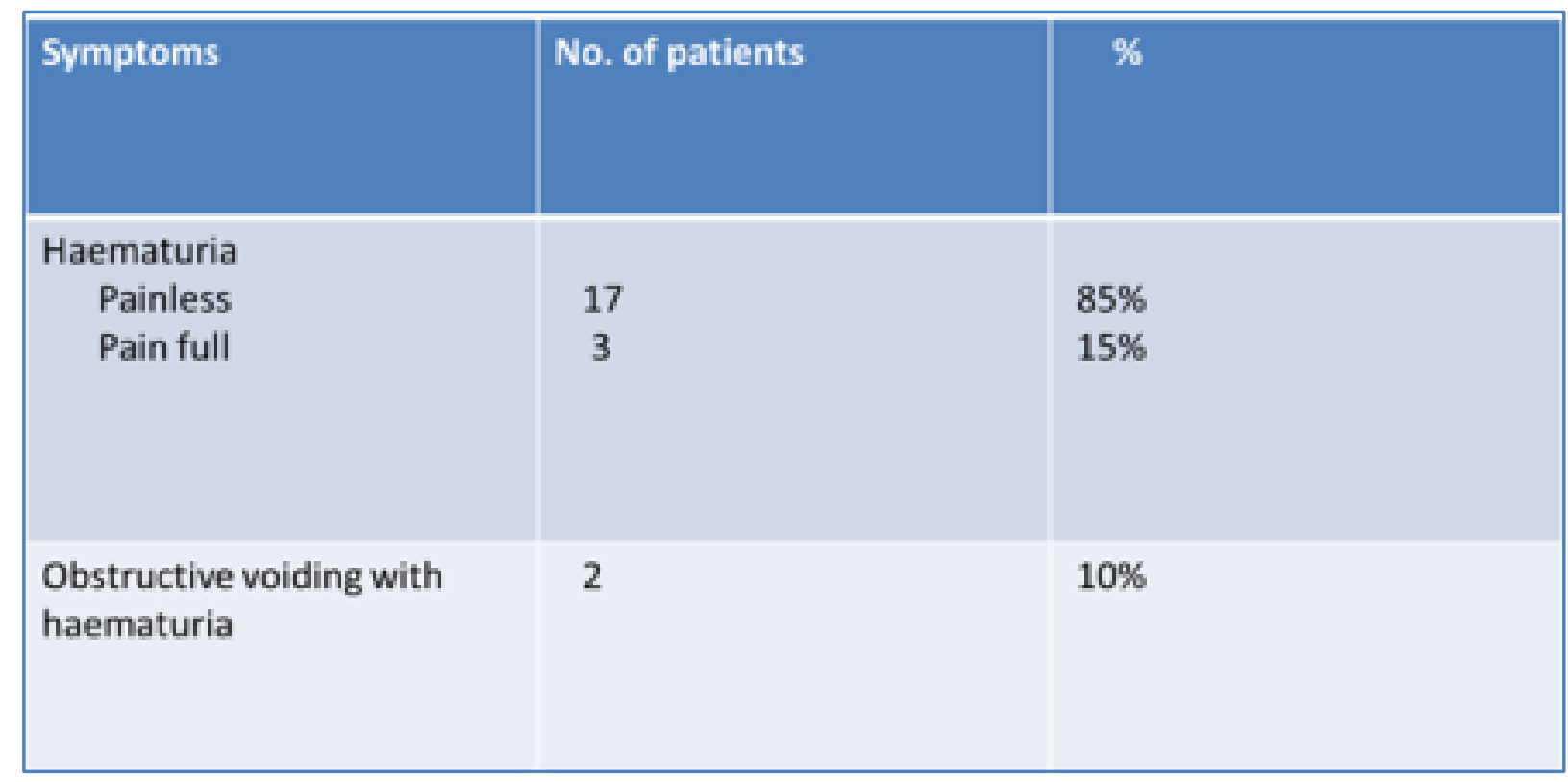

PERCENTAGE OF SYMPTOMS:

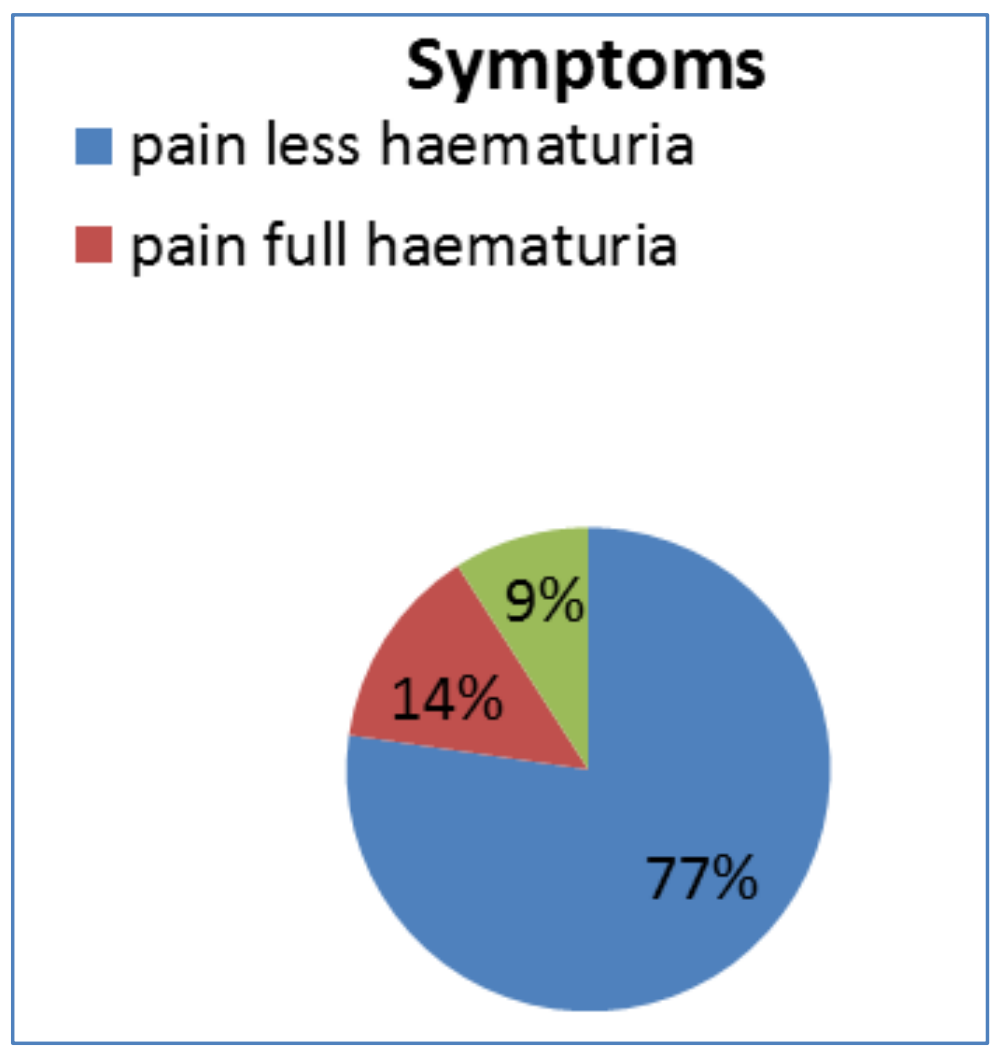


CASE STUDY

PERCENTAGE OF OTHER ORGANS INVOLVEMENT:

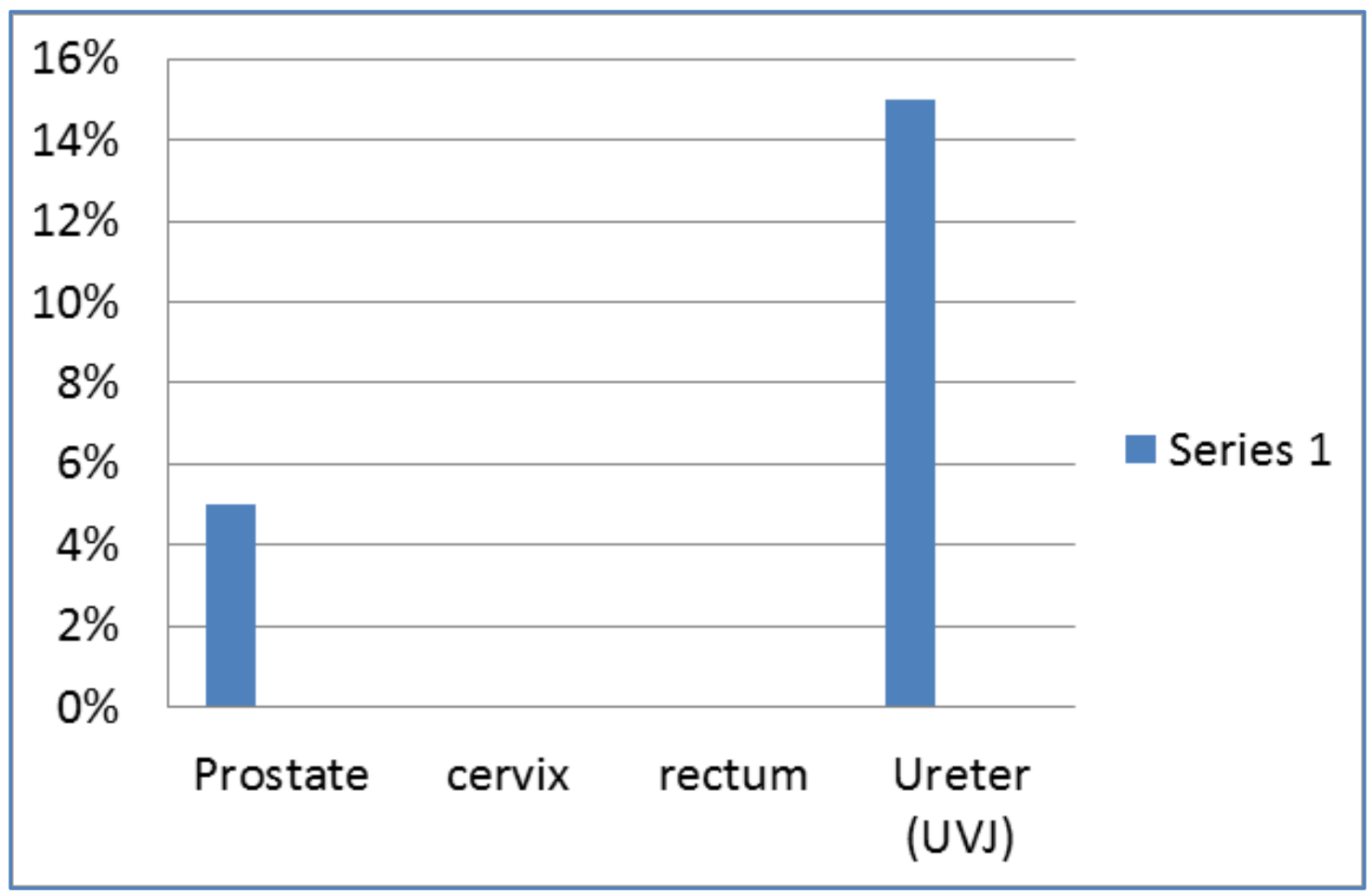

Histology:

\begin{tabular}{|l|l|l|}
\hline Type & No & $\%$ \\
\hline Transitional cell carcinoma & 19 & $95 \%$ \\
\hline Adenocarcinoma & 1 & $5 \%$ \\
\hline Squamous cell carcinoma & - & - \\
\hline Small cell carcinoma & - & - \\
\hline From other organs & - & - \\
\hline
\end{tabular}


CASE STUDY

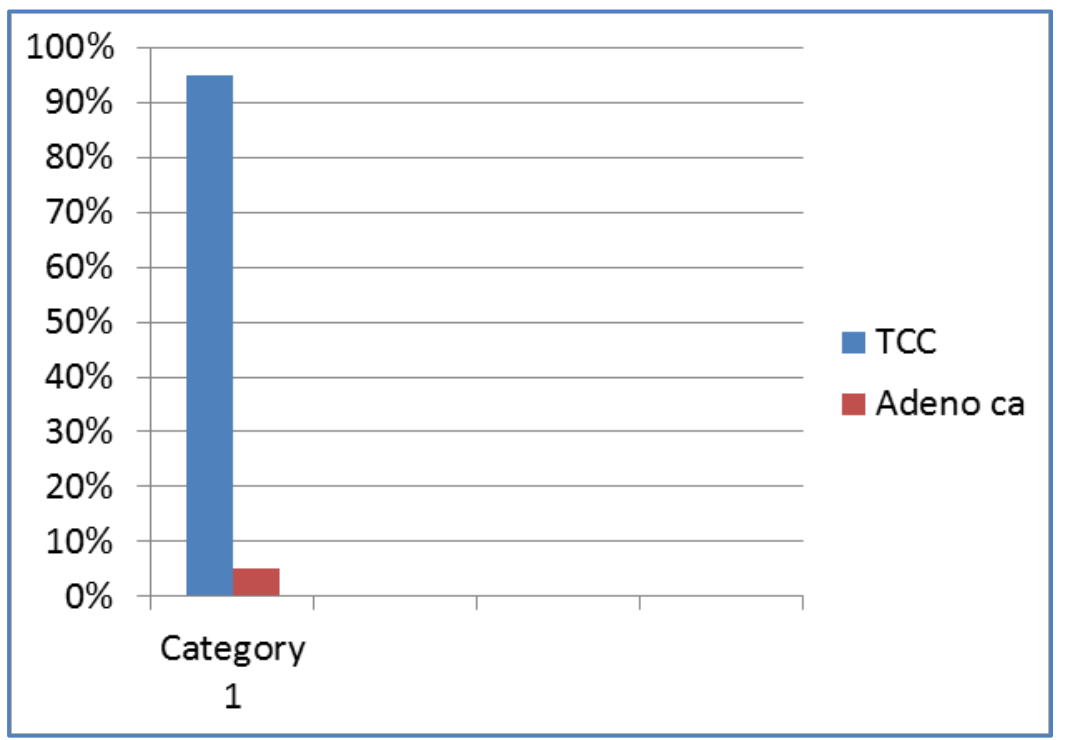

Tumor detected on USG/CT:

\begin{tabular}{|l|l|l|l|l|}
\hline Lesion & No & USG & CT & \% Corelation \\
\hline Solitary & 16 & 16 & 16 & $100 \%$ \\
\hline Multifocal & 4 & 4 & 4 & $100 \%$ \\
\hline
\end{tabular}

\section{TNM Staging for Bladder Cancer:}

\begin{tabular}{|c|c|}
\hline $\begin{array}{l}\text { TNM } \\
\text { Stage }\end{array}$ & Disease Extent \\
\hline $\mathrm{Ta}$ & $\begin{array}{l}\text { Non invasive papillary carcinoma, confined to urothelium and projecting towards } \\
\text { the lumen }\end{array}$ \\
\hline Tis & $\begin{array}{l}\text { Carcinoma in situ: flat tumor, high grade histologic features confined to the } \\
\text { urothelium }\end{array}$ \\
\hline T1 & Tumor invades subepithelial connective tissue (lamina propria) \\
\hline $\begin{array}{l}\mathrm{T} 2 \\
\mathrm{~T} 2 \mathrm{a} \\
\mathrm{T} 2 \mathrm{~b}\end{array}$ & $\begin{array}{l}\text { Tumor invades muscle } \\
\text { Tumor invades superficial muscle(inner half) } \\
\text { Tumor invades deep muscle (outer half) }\end{array}$ \\
\hline $\begin{array}{l}\text { T3 } \\
\text { T3a } \\
\text { T3b }\end{array}$ & $\begin{array}{l}\text { Tumor invades perivesical tissue } \\
\text { Tumor invades perivesical tissue microscopically } \\
\text { Tumor invades perivesical tissue macroscopically (extravesical mass) }\end{array}$ \\
\hline $\begin{array}{l}\text { T4 } \\
\text { T4a } \\
\text { T4b }\end{array}$ & $\begin{array}{l}\text { Tumor invades prostate or uterus or vagina or pelvic wall or abdominal wall } \\
\text { Tumor invades prostste or uterus or vagina } \\
\text { Tumor invades pelvic wall or abdomiinal wall }\end{array}$ \\
\hline
\end{tabular}




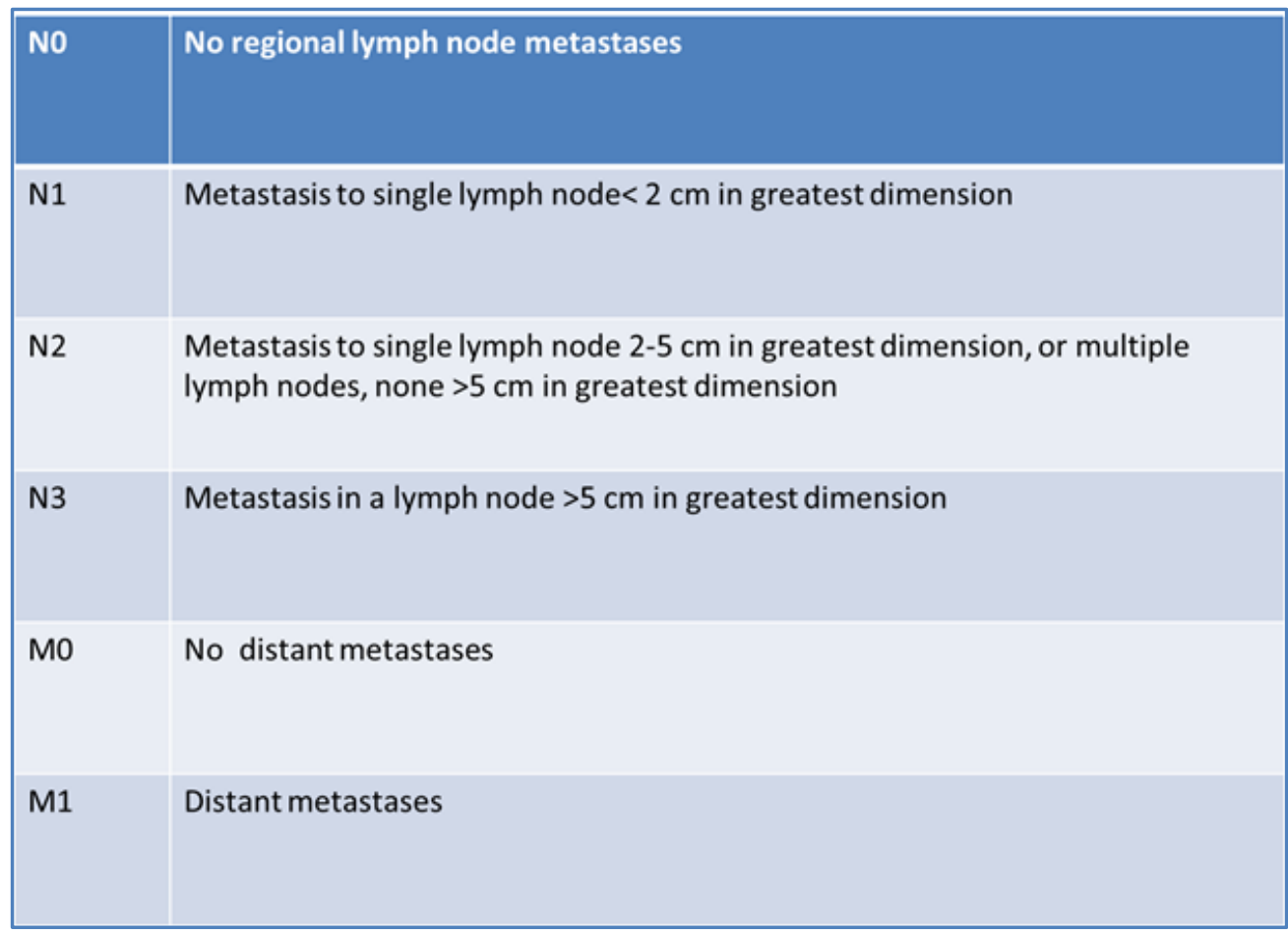

\section{DISCUSSION \& CONCLUSION:}

- Primary bladder tumors are most common in the age group of 51-70 years and in males.

- More common in males who were smokers.

- Most common presenting symptom is painless haematuria.(5)

- Majority of Bladder mass are solitary and are at Bladder base and lateral wall.

- Most common histological type is Transitional cell carcinoma.(6)

- Transabdominal USG being noninvasive, inexpensive and easily available modality can be used for screening of tumors and initial assessment of staging.

- MDCT scan plays a key role in evaluation of bladder neoplasms. ${ }^{(7)}$

- Tumor extension into adjacent organs and pelvis can be evaluated better by MDCT than USG.(7)

- Lymphnodal and distant metastasis are also better evaluated by MDCT.

- No significant difference in size, site, UVJ involvement detection was seen on USG and MDCT.

- In majority of cases the nodal metastasis were not well delineated on USG which were observed on MDCT and even bones metastasis if present can be seen on MDCT. Thus, tumor staging can be done by MDCT and USG. However MDCT is superior than USG for detection of distant metastasis. ${ }^{(7)}$

\section{BIBLIOGRAPHY:}

1. Murphy WM, Grignon DJ, Perlman EJ. Tumors of the kidney, bladder, and related urinary structures. Washington, DC: American Registry of Pathology, 2004; 394.

2. Moore KL. and Dalley AF (2006). Clinically oriented anatomy, Vol 1, 5th edn. Edited by Lippincott Williams \& Wilkins (Scientific Publishers, Lippincott Williams \& Wilkins) 176-180.

3. Stephanie R., Michelle M. and Stephen E. (2010). Anatomy for diagnostic imaging, 2nd edn. Edited by Saunders (Scientific Publishers, Saunders) 192-200. 


\section{CASE STUDY}

4. Carol M., Stephanie R., William J. and Deborah L. (2011). Diagnostic ultrasound, Vol 1, 2nd edn. Edited by Mosby (Scientific Publisher, Mosby) 87-93.

5. Kirkali Z, Chan T, Manoharan M, et al. Bladder cancer: epidemiology, staging and grading, and diagnosis. Urology. 2005; 66 (6 Suppl 1):4-34.

6. Amling CL. Diagnosis and management of superficial bladder cancer. Curr Probl Cancer. 2001; 25 (4):219-278.

7. Rajesh A, Sokhi H, Fung R, Mulcahy KA, Bankart MJ. Role of whole-body staging computed tomographic scans for detecting distant metastases in patients with bladder cancer. J Comput Assist Tomogr. 2011; 35 (3):402-405.

\section{AUTHORS:}

1. Sunny Goyal

2. Tushar Prabha

3. Mohan Shivnani

4. Ankur Aggarwal

5. Hemant Kumar Mishra

\section{PARTICULARS OF CONTRIBUTORS:}

1. P. G. Resident, Department of Radiodiagnosis, Mahatma Gandhi Medical College and Hospital, Jaipur.

2. Senior Resident, Department of Radiodiagnosis, Mahatma Gandhi Medical College and Hospital, Jaipur.

3. Professor, Department of Radiodiagnosis, Mahatma Gandhi Medical College and Hospital, Jaipur.
4. P. G. Resident, Department of Radiodiagnosis, Mahatma Gandhi Medical College and Hospital, Jaipur.

5. Professor and HOD, Department of Radiodiagnosis, Mahatma Gandhi Medical College and Hospital, Jaipur.

\section{NAME ADDRESS EMAIL ID OF THE CORRESPONDING AUTHOR:}

Dr. Sunny Goyal,

Room No. 103, PG Hostel, MGMCH, Sitapura, Jaipur-302022.

Email: dr.sunnygoel@gmail.com

Date of Submission: 15/10/2014. Date of Peer Review: 16/10/2014. Date of Acceptance: 05/11/2014. Date of Publishing: 10/11/2014. 